\title{
Latent Tüberküloz Enfeksiyonu Araştırılan Hastalarda QuantiFERON- TB GOLD Testi ile Tüberkülin Deri Testinin Karşılaştırılması
}

\section{Comparison of QuantiFERON-TB GOLD Test and Tuberculin Skin Test in Patients Investigated for the Presence of Latent Tuberculosis Infection}

\author{
İmge Say*๑, Burak Küçük*๑, Filiz Orak*๑, Murat Aral*๑, Adem Doğaner**๑ \\ * Kahramanmaraş Sütçü İmam Üniversitesi Tıp Fakültesi, Tıbbi Mikrobiyoloji Anabilim Dalı, Kahramanmaraş, Türkiye \\ ** Kahramanmaraş Sütçü İmam Üniversitesi Tıp Fakültesi, Biyoistatistik ve Tıbbi Bilişim Anabilim Dalı, Kahramanmaraş, Türkiye
}

Atıf/Cite as: Say I, Küçük B, Orak F, Aral M, Doğaner A. Latent tüberküloz enfeksiyonu araştırılan hastalarda QuantiFERON-TB GOLD testi ile tüberkülin deri testinin karşıllaşırılması. Turk Mikrobiyol Cemiy Derg. 2021;51(3):271-5.

Alındığı tarih / Received:

22.01.2021 / 22.January.2021

Kabul tarihi / Accepted:

24.03.2021 / 24.March.2021

Yayın tarihi / Publication date: 07.09.2021 / 07.September.2021

\section{ORCiD Kayıtları}

i. Say 0000-0001-7241-1202

B. Küçük 0000-0001-5596-3347

F. Orak 0000-0001-5153-7391

M. Aral 0000-0002-3576-4380

A. Doğaner 0000-0002-0270-9350

dr.burakkucuk@gmail.com öz

Amaç: Çalışmamızda, latent tübeküloz enfeksiyonu tanısında tüberkülin deri testi ile QuantiFERONTB Gold Plus (QFT-Plus) testinin tanısal değerinin belirlenmesi ve bu iki testin etkinliğinin karşılaştırılması amaçlanmıştır.

Yöntem: Çalışmamıza Ocak 2018-Şubat 2019 tarihleri arasında tüberküloz şüpheli QuantiFERONTB GOLD Plus testi ile tüberkülin deri testi sonuçları bulunan 134 hasta dâhil edilmiştir. Bulgular: Çalıșmamıza yaşları 5-80 arasında değișen 134 hasta alınmıștir. QFT-Plus pozitif olguların 26'sında TDT pozitif, 17'sinde TDT negatif bulunmuştur. Altmış dört hastada TDT pozitif olarak bulunmuştur. TDT pozitif hastaların 26'sında QFT-Plus pozitif, 38'inde QFT-Plus negatif bulunmustur. Dağılımsal farklılık istatistiksel olarak anlamlı saptanmıştır. QFT-Plus ve TDT testleri arasında ise uyum saptanmamıştir.

Sonuç: Sonuç olarak, LTBE araştırılmasında günümüzde hâlen rutinde kullanılmakta olan TDT'nin bazı dezavantajlarının olduğu göz önünde bulundurulduğunda, QFT-Plus testinin maliyeti yüksek olmasına karşın alternatif olarak kullanılabileceği düşünülmüştür.

Anahtar kelimeler: Latent tüberküloz, tüberkülin deri testi, quantiferon

\section{ABSTRACT}

Objective: In this study, we aimed to determine the diagnostic value of the tuberculin skin test (TST) and the QuantiFERON-TB Gold Plus (QFT-Plus) test in the diagnosis of latent tuberculosis infection and to compare the effectiveness of these two tests.

Method: One hundred and thirty-four patients aged between 5 and 80 with suspect tuberculosis having QuantiFERON-TB GOLD Plus test and Tuberculin skin test results were included in our study between January 2018 and February 2019.

Results: A total of 134 patients aged between 5-80 years were included in the study. In 26 of the QFT-Plus positive cases, TST was positive and in 17 of them TST were negative. TST was positive in 64 patients. Twenty six of TST positive patients were found to be QFT-Plus positive and 38 of them were QFT-Plus negative. The distributional difference was found to be statistically significant. There was no agreement between the QFT-Plus and TDT tests.

Conclusion: As a result, considering that TST, which is still used routinely today, has some disadvantages in LTBI research, it is thought that QFT-Plus test can be used as an alternative despite its high cost.

Keywords: Latent tuberculosis, tuberculin skin test, quantiferon 


\section{Giriş}

Tüberküloz (TB), Mycobacterium tuberculosis basilinin neden olduğu bir hastalıktır ${ }^{(1)}$. TB basillerinin vücuda farklı bulaş yolları (sindirim, solunum, konjonktiva, deri vb.) olmakla birlikte, ilk akla gelen bulaş yolu inhalasyondur(2). Vücuda alınan TB basili başlangıçta çoğalmaya başlar. Ancak enfeksiyon, gelişen immünite ile kontrol edilir. Bu duruma Primer enfeksiyon adı verilir. Primer enfeksiyonda klinik bulgu oluşmasa bile tüberkülin deri testi (TDT) pozitif sonuç verebilir. Bu sırada az miktarda basil, metabolizma hızlarını yavaşlatarak canlılıklarını sürdürebilir ve bu duruma latent tüberküloz enfeksiyonu (LTBE) adı verilir(3).

Son yıllarda kanser tedavileri, alerjik ve otoimmün hastalık tedavileri, transplant reddinin önlenmesi için yapılan tedaviler gibi immünsüpresif tedaviler yaygınlaşmaktadır. Bu yeni tedaviler terapotik etkilerinin yanı sıra toksisite, malignite ve enfeksiyon riski gibi istenmeyen durumlara da yol açabilmektedir. İmmünsüpressif ilaçlar, kronik kullanımları sırasında latent enfeksiyonun aktifleşmesine neden olabilir. $\mathrm{Bu}$ nedenle bu ilaçları kullanacak hastaların latent enfeksiyon yönünden değerlendirilmesi oldukça önemlidir ${ }^{(4)}$.

Tüberkülin deri testi latent tüberküloz enfeksiyonu tanısında kullanılan bir test olmasına karşın yanlış sonuçlar verebilmektedir. Örneğin, TDT'de pozitif sonuçlar, kişide $M$. tuberculosis dışında diğer atipik mikobakterilere maruz kalındığında da görülebilmektedir. Ayrıca, kronik hastalıklarda ve özellikle HIV hastalığı süresince immün sistem çok zayıflamakta, TDT'de yalancı negatif sonuçlara neden olabilmektedir ${ }^{(5)}$. Bu nedenlerle TDT'nin duyarlılığı ve özgüllüğü oldukça düşüktür. BCG aşılamasının yaygın şekilde uygulandığı ülkelerde TDT aşılamadan etkilenebileceği bilinmektedir. Bununla birlikte, uygulayan ve değerlendiren kişilerin farklı olabilmesi, tutulan kayıtlarla ilgili sorunlar ve tüberküline ait faktörler de TDT'nin yanlış sonuçlanmasına neden olabilmektedir. Bu nedenle aşılanma ve atipik mikobakterileri $M$. tuberculosis'ten ayırt edecek, hatta aktif hastalık ile LTBE arasında ayrım yapabilecek bir test gereksinimi vardır. Quantiferon testi kanda oluşan interferon gama (IFN- $\gamma$ ) seviyesini belirlemektedir. LTBE'nin saptanması immünsüpresif teda- vi alan hastalar için çok önemlidir. LTBE pozitif saptanan kişilere profilaktik INH tedavisi verilmektedir(6). Uzun süreli ilaç kullanımına bağı ıan etkiler ve maliyet, tedavi sürecindeki zorluklar, ilaç yükü düşünüldügünde LTBE'nin doğru saptanmasının ne kadar önemli olduğu ortaya çıkmaktadır.

Çalışmamızda, latent tübeküloz enfeksiyonu tanısında tüberkülin deri testi ile QuantiFERON-TB Gold Plus (QFT-Plus) testlerinin uyumu araştırılarak karşılaştırılması amaçlanmıştır.

\section{GEREÇ ve YÖNTEM}

Bu çalışma, Kahramanmaraş Sütçü İmam Üniversitesi, Klinik Araştırmalar Etik Kurulu tarafından (20.02.2019 tarih ve 35 No.) onaylanmıştır. Çalışmamıza Ocak 2018-Şubat 2019 tarihleri arasında QuantiFERON-TB GOLD Plus testi ile tüberkülin deri testi sonuçları bulunan latent tüberküloz şüpheli 134 hasta dâhil edilmiştir. Çalışmamız retrospektif türde bir çalışma olup, laboratuvar verileri taranarak yapılmıştır.

Tüberkülin deri testi uygulanması: Tüberkülin deri testi sol ön kolun $2 / 3$ üst kısmı iç ya da dış yüzüne 0.1 ml 5 Tüberkülin Ünitesi (TU) PPD (saflaştırılmış protein türevi=purified protein derivative), intradermal olarak uygulanmıştır. Endürasyon çapı 72 saat sonra aynı kişi tarafından okunmuş ve TDT değerlendirilmesi Şekil 1'de yer alan tablodaki kriterlere göre yapılmıştır.

QuantiFERON-TB Gold Plus (QFT-Plus) uygulanması: QFT-Plus, M. tuberculosis'e özgül antijenlere (ESAT-6 ve CFP-10) karşı hücreye bağımlı immün yanıtları saptamayayönelikbirtesttir. Çalışmamızda, QuantiFERONTB Gold Plus (QFT-Plus) kiti kullanılmıştır. Test için özel heparinli, vakumlu 4 ayrı test tüpüne (Nil tüpü, TB1 tüpü, TB2 tüpü ve bir Mitojen tüpü) 1'er ml periferik kan alınmıştır. Tüplerin iç kısımlarının yıkanması için tüpler 5 saniye çalkalanmıştır. $37^{\circ} \mathrm{C}^{\prime}$ lik etüvde $16-24$ saat bekletilip, inkübasyondan sonra tüpler 15 dakika santrifuj edilerek plazma kısmı ayrılmıştır. Peptid antijenlerine yanıt olarak üretilen IFN- $\gamma$ varlığı EnzymeLinked İmmunosorbent Assay (ELISA) yöntemi ile test edilmiştir. 
Tablo 1. TDT değerlendirilmesinde kabul edilen $\operatorname{kriterler}^{(7)}$.

\begin{tabular}{|c|c|c|}
\hline BCG aşısı yapılmış kişilerde & $\begin{array}{l}0-5 \mathrm{~mm} \\
6-14 \mathrm{~mm} \\
15 \mathrm{~mm} \text { ve üzeri }\end{array}$ & $\begin{array}{l}\text { Negatif } \\
\text { BCG aşııına bağlı } \\
\text { Pozitif }\end{array}$ \\
\hline \multirow[t]{2}{*}{ BCG aşısı olmayan kişilerde } & $\begin{array}{l}0-5 \mathrm{~mm} \\
6-9 \mathrm{~mm}\end{array}$ & $\begin{array}{l}\text { Negatif } \\
\text { Şüphelidir, test tekrarı yapılır; } \\
6-9 \mathrm{~mm} \text {; negatif (immun baskılanmada }>5 \mathrm{~mm} \text { pozitif) } \\
10 \mathrm{~mm} \text { ve üzeri pozitif }\end{array}$ \\
\hline & 10 mm ve üzeri & Pozitif \\
\hline
\end{tabular}

Istatiksel analiz: Verilerin değerlendirmesinde kategorik değişkenler arasındaki dağılım ilişkisi ki-kare testi ile incelenmiştir. Testler arasındaki uyumluluk kappa katsayısı ile incelenmiştir. Veriler oran ve frekans olarak verilmiştir. İstatistiksel anlamlılık için $p<0.05$ değeri kabul edilmiş ve veriler IBM SPSS 22 programında değerlendirilmiştir.

\section{BULGULAR}

Çalışmamıza yaşları 5-80 arasında değişen 134 hasta alınmıştır. Hastaların 58'i (\%43) kadın, 76'sı (\%57) erkek hastadan oluşmaktadır. Hastaların klinik dağılımına bakıldığında, 55 Enfeksiyon Hastalıkları, 45 Göğüs Hastalıkları, 16 Nöroloji, altı Dermatoloji, beş Çocuk Hastalıkları, dört Dâhiliye ve üç Beyin Cerrahisi Anabilim Dalı hastası olduğu belirlenmiştir. Olguların 43'ünde QFT-Plus testi pozitif bulunmuştur. QFT-Plus pozitif olguların 26'sında TDT pozitif, 17'sinde TDT negatif bulunmuştur. Altmış dört hastada TDT pozitif olarak bulunmuştur. TDT pozitif hastaların 26 'sında QFT-Plus pozitif, 38'inde QFT-Plus negatif bulunmuştur (Tablo 1). Dağılımsal farklılık istatistiksel olarak anlamlı saptanmıştır $\left(\chi^{2}=4.096 ; p=0.043\right)$. QFT-Plus ve TDT testleri arasında ise uyum saptanmamıştır ( $\mathrm{k}=0.166)$.
LTBE araştırılan olguların 25'inde eşzamanlı tüberküloz kültürü istenmiş olup, hepsinin kültür sonuçları negatif sonuçlanmıştır. Bu 25 hastanın 12'sinde QFT ve PPD testlerinin her ikisi de negatif, ikisinde her ikisi de pozitif, sekizinde QFT negatif PPD pozitif, üçünde ise QFT pozitif PPD negatif olarak saptanmıştır.

Olguların sekizi HIV pozitif olupi altısında QFT ve PPD testlerinin her ikisi de negatif, birinde her ikisi de pozitif, birinde ise QFT pozitif PPD negatif olarak saptanmıştır.

\section{TARTIŞMA}

Tüberkülin deri testi uzun zamandır aktif ve latent tüberküloz teşhisi için kullanılmaktadır. TDT'nin maliyeti düşüktür ve uygulanması için ek bir altyapıya gereksinim yoktur. Bu avantajlarının yanı sıra bazı dezavantajları da bulunmaktadır. Tüberkülinde bulunan $M$. tuberculosis'e spesifik olmayan mikobakteriyel antijenler testin yanlış pozitif sonuçlanmasına neden olabilmektedir ${ }^{(5)}$. Aynı şekilde immünsüpressif hastalarda çıkan negatif sonuçlar, hastaların gerekli uyumu göstermemesi, sonucu okuyan kişilerin farklı değerlendirmeleri yanlış sonuçlara neden olabilmektedir. LTBE tanısında geçmişte kullanılan ve günü-

Tablo 2. Olguların pozitiflik negatiflik dağılımı.

\begin{tabular}{|c|c|c|c|c|c|c|c|c|c|}
\hline & \multicolumn{2}{|c|}{ Negatif } & \multicolumn{2}{|c|}{ Pozitif } & \multicolumn{2}{|c|}{ Toplam } & \multirow[b]{2}{*}{$\chi^{2}$} & \multirow[b]{2}{*}{$\mathbf{p}$} & \multirow[b]{2}{*}{$\mathbf{K}$} \\
\hline & $n$ & $\%$ & $\mathbf{n}$ & $\%$ & $n$ & $\%$ & & & \\
\hline \multicolumn{10}{|l|}{ QFT } \\
\hline Negatif & 53 & 58.2 & 38 & 41.8 & 91 & 100.0 & 4.096 & $0.043^{*}$ & $0.166^{a}$ \\
\hline Pozitif & 17 & 39.5 & 26 & 60.5 & 43 & 100.0 & & & \\
\hline Toplam & 70 & 52.2 & 64 & 47.8 & 134 & 100.0 & & & \\
\hline
\end{tabular}

*Dağılımsal farklılık istatistiksel olarak anlamlı saptanmıştır.

${ }^{a} i k i$ test arasında uyum saptanmamıştır. 
müzde kullanılmaya devam edilen bu testin yalancı pozitif ve negatif sonuçlar verebilmesi, duyarlılığı ve özgüllüğü daha yüksek tanı araçlarının geliştirilmesini zorunlu kılmışır. Yakın zamanda TDT'ye eş değer fakat daha özgül olarak üretilen testlerin çalışma ilkesi, kişilerin tüberküloz antijenleri ile karşılaştıklarında salınan IFN- $\gamma$ miktarının ölçülmesi esasına dayanmaktadır(8). Hücresel IFN- $\gamma$ seviyesini ölçen metotlardan birisi olan QuantiFERON-TB Gold ELISA testinin kan alınarak yapılması, uygulamasının basit olması, daha spesifik antijenlere sahip olması TDT'ye göre daha avantajlı olmasını sağlamıştır.

BCG aşısının yanlış pozitif TDT sonuçlarına yol açabilmesi nedeniyle IFN-gama testlerinin daha kullanışlı olduğu yapılan çalışmalarda bildirilmiştit ${ }^{(9,10)}$. Aşı anında uygulanan aşı miktarı, çocuğun yaşı ve uygulama aralığı BCG aşısı sonrası meydana gelen TDT değerini etkilemektedir ${ }^{(11,12)}$. Gelişmiş ülkelerde BCG aşısı yapılmadığı ya da tek doz olarak uygulandığı için BCG aşısından TDT'nin etkilenmediği, az ve orta gelişmiş ülkelerde ise TDT duyarlılığının etkilendiği yapılan birçok çalışmada bildirilmiştir ${ }^{(13,14)}$. Yapılan çalışmalara bakıldığında, Pai ve ark. ${ }^{(15,16)}$ yaptıkları iki farklı derlemede geçmişte yapılan BCG aşısının interferon gama salınım testlerinin (IGST) sonuçlarını etkilemediğini bildirmişlerdir. Diel ve ark. ${ }^{(17)} 309$ temaslı hastayı içeren bir çalışmada, QFT-G test sonuçlarının BCG aşılamasından etkilenmediği sonucuna varmışlardır. Okada ve ark. ${ }^{(18)}$ temaslı beş yaş altı 195 çocuk içeren çalışmada; BCG aşıIı ve QFT-G testi sonuçlarının istatistiksel bir fark içermediğini bildirmişlerdir. Yapılan bir diğer çalışmada, BCG aşısı bulunan hastalarda TDT ve QFT-G testleri arasındaki uyum \%41.5 bulunup, aşısız hastalarda ise bu oran \%80.3 olarak bildirilmiştir. Aradaki fark BCG aşısının TDT'ye etkisi olarak yorumlanmıştır ${ }^{199}$. BCG aşı sayısı ve TDT endürasyon çapı karşılaştırması üzerine Bozkanat ve ark.'nın ${ }^{(20)}$ askeri okulda yaptıkları bir çalışmada, iki test arasında istatistiksel olarak uyum saptanmıştır.

QFT-G testi ile TDT karşılaştııılan çalışmalara bakıldığında, Çavuşoğlu ve ark. ${ }^{(21)}$ yaptıkları çalışmada, QFT testinin duyarlılığının TDT'den daha yüksek olduğunu, QFT'nin LTBE tanısında altın standart olmadığını, QFT testinin sonuçlarının aktif TB gelişme riskini daha doğru olarak gösterdiğini bildirmişlerdir. Çağlayan'ın ${ }^{(22)}$, hastane çalışanlarında LTBE tanısında QFT-G ile TDT testinin kıyaslanması üzerine yaptığı çalışmasında, iki test arasında anlamlı korelasyon saptanmıştır. QFT-G pozitifliğinin TDT endürasyon çapı $>10 \mathrm{~mm}$ olan kişilerde arttığı belirtilmiştir. Kanada Tüberküloz Komitesi'nin rehberinde ise bağışıklığı baskılanmış grupta IGST performansının değişkenlik göstermesi nedeniyle LTBE tanısı için ilk olarak TDT yapılması, TDT negatif olduğunda veya klinisyenin TDT negatif olduğu halde, TB şüphesi olduğu durumda iGST yapılması önerilmektedir ${ }^{(23)}$. Ülkemiz için LTBE tanısında test seçimi önerilerine bakıldığında öncelikle TDT tercih edilmekle birlikte, immünsüpresif ya da immünsüpresif tedavi adayı olan hastalara IGST yapılması önerilmektedir ${ }^{(24)}$. Tüm bunların yanında QFT-G testinin bağışıklığı baskılanmış hastalarda yanlış negatif sonuç verebilmesi, tedavi takibinde kullanılamaması ve pahalı olması gibi olumsuz yönleri de vardır ${ }^{(25)}$.

Bizim çalışmamızda da dağılımsal farklılık istatistiksel olarak anlamlı bulunmuş ve bu iki test arasında uyum saptanmamıştır. Yani TDT uygulaması yapan personelin hastanın BCG aşısını dikkate alarak okuma yapması, immünsüpresse bir durumu olup olmadığının sorgulanması, hastaya 72 saat içerisinde dikkat edeceği hususlar hakkında yeterince bilgi verilmesi gibi durumları gözden geçirmemiz gerekliliğini ortaya koymuştur. Sonuç olarak, LTBE araştırılmasında günümüzde hâlen rutinde kullanılmakta olan TDT'nin bazı dezavantajlarının olduğu göz önünde bulundurulduğunda QFT-Plus testinin maliyeti yüksek olmasına karşın alternatif olarak kullanılabileceği düşünülmektedir.

Etik Kurul Onayı: Bu çalışma, Kahramanmaraş Sütçü İmam Üniversitesi, Klinik Araştırmalar Etik Kurulu tarafından (20.02.2019 tarih ve 35 No.) onaylanmıştır.

Çıkar Çatışması: Yazarlar bu makale ile ilgili herhangi bir çıkar çatışması bildirmemişlerdir.

Ethics Committee Approval: The study protocol was approved by the Kahramanmaraş Sutcu Imam University Ethics Committee (02.20.2019-35).

Conflict of Interest: No conflict of interest was declared by the authors. 


\section{KAYNAKLAR}

1. WHO. Tuberculosis Fact sheet Number 104. Geneva: World Health Organization. 2010. [https://www.who. int/en/news-room/fact-sheets/detail/tuberculosis] (Erişim tarihi: 24.Mart.2021)

2. Dye C, Scheele S, Dolin P, Pathania V, Raviglione MC. Consensus statement. Global burden of tuberculosis: estimated incidence, prevalence, and mortality by country. WHO Global Surveillance and Monitoring Project. JAMA. 1999;282(7):677-86.

https://doi.org/10.1001/jama.282.7.677

3. Özkara Ş, Aktaş Z, Özkan S, Ecevit H. Türkiye Cumhuriyeti Sağıı Bakanlığı Verem Savaş Daire Başkanlığı Türkiye'de tüberküloz kontrolü için başvuru kitabı. Ankara, 2003:7-62.

4. Oral HB. İmmünmodülatörler, immünsüpresifler ve enfeksiyon riski. Ankem Derg. 2007;21(Ek 2):E106-8.

5. Chaparas SD, Vandiviere HM, Melvin I, Koch G, Becker C. Tuberculin test: varibiality with the Mantoux procedure. Am Rev Respir Dis. 1985;132(1):175-7. https://doi.org/10.1164/arrd.1985.132.1.175

6. Iseman MD. Klinisyenler İçin Tüberküloz Kılavuzu. Çeviren: Ş. Özkara. Nobel Tıp Kitapevleri Ltd. Şti. 2002: 21-402.

7. TC. Sağlık Bakanlığı Verem Savaşı Daire Başkanlığı. Türkiye'de Tüberkülozun Kontrolü İçin Başvuru Kitabı. Ankara, 2003:55-7.

8. Mori T, Sakatani M, Yamagishi F, et al. Specific detection of tuberculosis infection: an interferon-gamma-based assay using new antigens. Am J Respir Crit Care Med. 2004;170(1):59-64.

https://doi.org/10.1164/rccm.200402-1790C

9. Brock I, Weldingh K, Lillebaek T, Follmann F, Andersen P. Comparison of tuberculin skin test and new specific blood test in tuberculosis contacts. Am J Respir Crit Care Med. 2004;170(1):65-9.

https://doi.org/10.1164/rccm.200402-2320C

10. Rieder HL. Epidemiological basis of tuberculosis control. Paris: International Union Against Tuberculosis and Lung Disease (The Union). 1999:26-43.

11. Wang L, Turner MO, Elwood RK, Schulzer M, FitzGerald JM. A meta-analysis of the effect of Bacille Calmette Guerin vaccination on tuberculin skin test measurements. Thorax. 2002;57(9):804-9. https://doi.org/10.1136/thorax.57.9.804

12. Lockman S, Tappero JW, Kenyon TA, Rumisha D, Huebner RE, Binkin NJ. Tuberculin reactivity in a pediatric population with high BCG vaccination coverage. Int J Tuberc Lung Dis. 1999;3(1):23-30.

13. Chadha VK, Jagannatha PS, Kumar P. Can BCG vaccinated children be included in tuberculin surveys to estimate the annual risk of tuberculosis infection in India. Int J Tuberc Lung Dis. 2004; 8: 1437-42.

14. Ewer K, Deeks J, Alvarez L, et al. Comparison of T-cell based assay with tuberculin skin test for diagnosis of Mycobacterium tuberculosis infection in a school tuberculosis outbreak. Lancet. 2003;361(9364):116873.

https://doi.org/10.1016/S0140-6736(03)12950-9

15. Pai M. Riley LW, Colford Jr JM. Interferon gama assays in the immunodiagnosis of tuberculosis: a systematic review. Lancet Infect Dis. 2004;4(12):761-76. https://doi.org/10.1016/S1473-3099(04)01206-X

16. Pai $M$, Kalantri S, Dheada K. New tools and emerging technologies for the diagnosis of tuberculosis: part I. Latent tuberculosis. Expert Rev Mol Diagn. 2006;6(3):413-22. https://doi.org/10.1586/14737159.6.3.413

17. Diel R, Nienhaus A, Lange C, Meywald-Walter K, Forssbohm M, Schaberg T. Tuberculosis contact investigation with a new, specific blood test in a lowincidence population containing a high proportion of BCG-vaccinated persons. Respir Res. 2006;7(1):1-9. https://doi.org/10.1186/1465-9921-7-77

18. Okada K, Mao TE, Mori T, et al. Performance of an interferon-gama release assay for diagnosing latent tuberculosis infection in children. Epidemiol Infect. 2008;136(9):1179-87. https://doi.org/10.1017/S0950268807009831

19. Ferrara G, Losi M, Meacci M, et al. Routine hospital use of a new commercial whole blood interferon-gama assay for the diagnosis of tuberculosis infection. Am J Respir Crit Care Med. 2005;172(5):631-5.

https://doi.org/10.1164/rccm.200502-1960C

20. Bozkanat E, Çiftçi $F$, Apaydın $M$, et al. İstanbul il merkezinde bir askeri okulda tüberkülin cilt testi taraması. Tuberk Toraks. 2005;53(1):39-49.

21. Çavuşoğlu C, Durusoy R, Yaşar M, Kayın M. Mycobacterium tuberculosis enfeksiyonu tanısında QuantiFERON ${ }^{\circledR}$-TB Gold in Tube testi ve tüberkülin deri testinin değerlendirilmesi. Mikrobiyol Bul. 2017;51(2):115-26. https://doi.org/10.5578/mb.53842

22. Çağlayan V. Hastane çalışanlarında latent tüberküloz enfeksiyonu tanısında tüberkülin cilt testi ile Quantiferon-TB Gold testinin karşılaştırılması. [Tıpta Uzmanlık Tezi]. İstanbul: Sağlık Bakanlığı Süreyyapaşa Göğüs ve Kalp- Damar Hastalıkları Eğitim ve Araştırma Hastanesi, 2004:59.

23. Kunimoto D, Gardam DM, Kitail, etal. Recommendations on interferon gamma release assays for the diagnosis of latent tuberculosis infection-2010 Update. Can Commun Dis Rep. 2010;36(ACS-5):1-22. https://doi.org/10.14745/ccdr.v36i00a05

24. Kara F. Tüberküloz Tanı ve Tedavi Rehberi. Sağlık Bakanlığı Yayın No: 1129. Ankara, 2019:1-33.

25. Ndzi EN, Nkenfou CN, Gwom LC, Fainguem N, Fokam J, Pefura Y. The pros and cons of the QuantiFERON test for the diagnosis of tuberculosis, prediction of disease progression, and treatment monitoring. Int J Mycobacteriol. 2016;5(2):177-84. https://doi.org/10.1016/j.ijmyco.2016.02.005 